Rok XIV (2019) | 2 (28) | s. 135-144

https://doi.org/10.12797/LV.14.2019.28.09

Mirosław Jankowiak (1)

Akademie věd České republiky, Praga

mirek.jankowiak@gmail.com

\title{
RELIKTY POLSZCZYZNY PÓŁNOCNOKRESOWEJ NA RUBIEŻACH DAWNEJ RZECZYPOSPOLITEJ (POŁUDNIOWE ZIEMIE OBWODU PSKOWSKIEGO). CZ. II
}

Słowa klucze: dialektologia słowiańska, polszczyzna północnokresowa, gwary białoruskie, gwary rosyjskie, zapożyczenia, leksyka

Keywords: Slavic dialectology, Polish of the North-Eastern Borderland, Belarusian dialects, Russian dialects, loanwords, vocabulary

\section{Wprowadzenie}

W pierwszej części publikacji omówiono sytuację socjolingwistyczną (zakres użycia polszczyzny północnokresowej w różnych okresach historycznych) oraz wybrane zapożyczenia z języka polskiego lub przyjęte za polskim pośrednictwem występujące w gwarach południowej części obwodu pskowskiego. Opis odnosił się geograficznie do obszaru wchodzącego w skład Rzeczypospolitej do okresu pierwszego rozbioru w 1772 r. Niniejszy artykuł, będący drugą częścią publikacji, prezentuje wpływy polskie w dwóch regionach o odmiennej historii, warunkach społecznych i przynależności administracyjnej - w rejonie pytałowskim (należącym do Łotwy w okresie międzywojennym) oraz na obszarze historycznej Pskowszczyzny

1 Cz. I zob. „LingVaria” 2019, nr 1 (27), s. 149-164. 
(tj. dawnej guberni pskowskiej). Podstawę materiałową stanowią dwa słowniki Regionalny słownik pskowski $z$ danymi historycznymi (POS) oraz Dialektologiczny słownik jednej rodziny - 2 (rejon pytałowski obwodu pskowskiego) (Korolëva 2013).

\section{Uwarunkowania historyczne i sytuacja socjolingwistyczna}

\section{Rejon pytałowski}

Okolice dzisiejszego Pytałowa należały w średniowieczu historycznie i kulturowo do Łatgalii, o czym miałaby świadczyć sama nazwa (Pytałowo < Pietālava < pie. Tālavas, czyli ziemie przy starołatgalskiej krainie historycznej Tālava). Przez dłuższy okres swoich dziejów obszar ten wchodził jednak w skład historycznej Pskowszczyzny (guberni pskowskiej), a tym samym Państwa Moskiewskiego, a później Imperium Rosyjskiego. Ukształtowało to bardzo wyraźnie sytuację językową, wyznaniową i kulturową. Zmiany administracyjne nastąpiły dopiero po I wojnie światowej, kiedy Łotysze z pomocą Polaków wyzwolili spod władzy Rosjan Łatgalię, co umożliwiło im przejęcie również rejonu pytałowskiego (nazywanego w latach 1925-1938 Jaunlatgale, a w latach 1938-1945 Abrene). Oficjalnie wszedł on w granice Łotwy w $1921 \mathrm{r}$. w wyniku traktatu ryskiego. Po II wojnie światowej został przyłączony do Rosyjskiej Federacyjnej SRR i obecnie znajduje się w granicach Federacji Rosyjskiej. Jeszcze do niedawna był to obszar sporny między Rygą a Moskwą i dopiero w 2007 r. - po rezygnacji z roszczeń ze strony Łotwy - Rosja zaakceptowała całą granicę łotewsko-rosyjską.

W 1935 r. ludność łotewska stanowiła w rejonie Jaunlatgale prawie 55\% mieszkańców (z czego na obszarze znajdującym się obecnie w Rosji zamieszkiwało²: 3765 Łotyszy, 29437 Rosjan, 301 Polaków, 102 Żydów i 52 Białorusinów (Spis powszechny)). W latach 30. XX w. prawosławni stanowili tam 48\%, katolicy 38\% (głównie Łatgalczycy), a luteranie $12 \%$. Funkcjonowało szkolnictwo łotewskie, łatgalskie oraz szkolnictwo mniejszości narodowych. Obecnie zamieszkuje tu tylko około 70 osób narodowości łotewskiej, co stanowi poniżej 1\%, a spis powszechny z 2004 r. nie wykazuje Polaków ani ludności białoruskiej (Dannye vserossijskoj).

Teren ten charakteryzowało zatem w przeszłości funkcjonowanie języka rosyjskiego w postaci głównie gwary pskowskiej, a obecnie także języka rosyjskiego zbliżonego do literackiego, gwar łatgalskich, języka łotewskiego (administracja, szkoły) oraz gwar białoruskich (wioski). Do chwili obecnej brak jest dostępnych prac naukowych, które wskazywałyby na funkcjonowanie języka polskiego na tym ob-

2 Rejon Jaunlatgale (późniejszy rejon Abrene) obejmował ziemie, które obecnie znajdują się po obydwu stronach granicy łotewsko-rosyjskiej, dlatego też informacje i dane statystyczne odnoszą się tylko do obszaru, który po II wojnie światowej wszedł w granice Rosyjskiej SRR. 
szarze. Najprawdopodobniej posługiwano się nim w posiadłościach wiejskich oraz miasteczkach typu Jaunlatgale (mieszkało tam w 1935 r. 22 Polaków) oraz w Wyszgorodku (44 Polaków w 1935 r.), czyli w powiecie, z którego pochodzą wypowiedzi respondentów wykorzystane w Dialektologicznym słowniku jednej rodziny. Kwestia pochodzenia Polaków w rejonie pytałowskim wymaga badań archiwalnych, najprawdopodobniej byli to jednak Polacy przybyli tam w okresie międzywojennym, czyli za tzw. „czasów łotewskich”. W miasteczkach pełnili zapewne funkcje administracyjne, mieszkali również na wsi, ale nie byli miejscowymi posiadaczami ziemskimi. Na Łotwie bowiem, po pierwsze, w 1921 r. miała miejsce reforma agrarna, na której podstawie odebrano właścicielom ziemskim sporą część majątków, po drugie, Polacy byli ludnością napływową po $1920 \mathrm{r}^{3}{ }^{3}$ Jak podaje ówczesna prasa, na interesującym nas obszarze wielu Polaków stanowili sezonowi pracownicy z Polski. Takich Polaków w rejonie Jaunlatgale w 1936 r. było 43, do pracy przyjeżdżali także Litwini (19 osób), Estończycy (26 osób) oraz „bezpaństwowcy” (116 osób) (Jaunlatgales). $\mathrm{Z}$ danych statystycznych wynika zatem, że przybyli tam do pracy Polacy pochodzili zarówno z obszaru Łotwy, jak i z II Rzeczypospolitej. Uwarunkowania historyczno-społeczne dają podstawy sądzić, że w przypadku pracowników sezonowych przybyłych spoza Łotwy należy mówić o osobach z północno-wschodniej Polski, a w przypadku łotewskich Polaków o ludności z biedniejszej Łatgalii (z bogatszej Kurlandii czy Semigalii nie wyjeżdżano na roboty na wschód kraju). Ich mowę należałoby zatem uznać za polszczyznę północnokresową, a dokładniej odmianę łotewską opisaną w publikacjach Józefy Parszuty (m.in. Paršuta 1984), Małgorzaty Ostrówki (m.in. Ostrówka 1999, 2000, 2002; Ostrówka, Golachowska 2018 i in.) oraz Krystyny Kunickiej (m.in. Kunicka 2012, 2016), lub polszczyznę z obszaru północno-wschodniej II Rzeczypospolitej (por. Smułkowa 2009; Rieger 2014; Karaś 2017).

Elementy polskie występujące w mowie miejscowej ludności rosyjskojęzycznej i zanotowane w Dialektologicznym słowniku jednej rodziny mają zatem różne pochodzenie. Mogą to być zapożyczenia polskie w gwarach pskowskich funkcjonujące $\mathrm{w}$ nich od dawna oraz nowsze $\mathrm{z}$ okresu międzywojennego. Zachowaniu polonizmów sprzyjały przede wszystkim dwa czynniki - bliskość geograficzna oraz pośrednictwo języków/gwar bałtyckich (głównie łatgalskich) oraz gwar białoruskich.

Obecnie bez badań archiwalnych trudno jest odtworzyć dokładny zakres funkcjonowania języka polskiego $\mathrm{w}$ rejonie pytałowskim. Polszczyzna miała tam niewątpliwie charakter wyspowy, jak na obszarze rejonu siebieskiego i newelskiego, a jej użycie ograniczało się zapewne do sfery rodzinnej i być może sąsiedzkiej. W sferze religijnej język polski najprawdopodobniej ograniczał się do prywatnej modlitwy.

3 Na podstawie rozmowy z prof. Ėriksem Jēkabsonsem, łotewskim historykiem, specjalizującym się w dziejach Polaków na Łotwie; rozmowa z dnia 23 X 2018 r. 


\section{Pskowszczyzna}

Historyczna Pskowszczyzna nigdy nie wchodziła w skład administracyjnych granic Wielkiego Księstwa Litewskiego i Rzeczypospolitej, natomiast jej położenie (bliskość geograficzna m.in. z Inflantami polskimi), a co za tym idzie i wymiana handlowa powodowały, że miejscowa ludność miała kontakt z językiem polskim, o czym pisała w swoim artykule Iryda Grek-Pabisowa (1986: 185). Dialektowi pskowskiemu oraz językowi dawnych tekstów pskowskich poświęcono już liczne publikacje, które tutaj nie będą omawiane, z publikacji warto natomiast wspomnieć najnowszą pracę wieloautorską, liczącą ponad 400 stron (Pskovskie govory), a z białoruskich lingwistów Jana Stankiewicza (Stankevič 1962).

Historyczna Pskowszczyzna to obszar rosyjskojęzyczny, gdzie funkcjonują gwary pskowskie oraz język rosyjski, a w mowie miejscowej ludności można do dzisiaj odnaleźć pojedyncze zapożyczenia - dawne bałtyzmy, białorutenizmy i polonizmy, a także słowa $\mathrm{z}$ dialektów bałto-fińskich. Na obszarze tym nie było w przeszłości osadnictwa polskiego, nie licząc pojedynczych osób (np. kupców).

\section{Wybrane polonizmy leksykalne w Dialektologicznym słowniku jednej rodziny - 2 (rejon pytałowski obwodu pskowskiego)}

Słownik poza nielicznymi białorutenizmamami (np. батька 'ојсіес', ведать 'wiedzieć', дровы 'drewno', жыхар 'mieszkaniec', колидор 'korytarz', малеи 'młody chłopak', откуль 'skąd', покуль 'póki') oraz leksemami bałtyckiego i łotewskiego

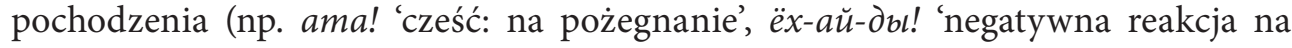
otrzymaną informację, о cholera', пуня 'stodoła') zawiera również szereg polonizmów. Poniżej prezentuję kilka wybranych wyrazów ${ }^{4}$ :

БАТЬЯ્H5 'bocian’. „Надо ж, где гнездечко свили батьяны” (Korolëva 2013: 21), z języka polskiego (< pol. bocian; ÈSRÂA I: 201; ÈSBM I: 336, 337), występuje w gwarach białoruskich północno-zachodniego pogranicza, w tym na Litwie i Łotwie (SPZB I: 276; materiały własne autora), w SRNG przykłady podane tylko dla obwodu pskowskiego (SRNG III: 139). Notowany także w gwarach łatgalskich (LVDA, karta 36). Słowo funkcjonuje w polszczyźnie północnokresowej, w tym na Brasławszczyźnie (SMPPK: 112; Smułkowa 20o9: 36).

4 Słowniki SMPPK oraz Rieger 2014 mają charakter dyferencyjny i nie uwzględniają leksyki ogólnej; jeżeli analizowane słowo nie było w nich zanotowane, nie podaję informacji o tym przy omawianym wyrazie.

5 Podobnie jak w pierwszej części artykułu podkreśleniem zaznaczone zostały samogłoski akcentowane. 
ВЛАСТИТЕЛЬ 1. 'osoba będąca w stanie odpowiadać za swoje postępowanie' „Как говорят: дитё сам не властитель”; 2. 'właściciel' „А кто властители?” (Коrolëva 2013: 45), najprawdopodobniej z języka polskiego (< pol. właściciel), brak hasła w: ĖSRÂ, ĖSBM, Bulyka 1972, w SRNG przykłady tylko z obszaru Litwy i Łotwy (SRNG IV: 318).

ГВАЛТ 'głośny krzyk o pomoc'. „Она с этого со хлева гробых-гробых, подняла гвалт «Меня убить хочет!»" (Korolëva 2013: 64), za polskim pośrednictwem (pol. gwatt < śrwysniem. gewalt; ĖSRÂ I: 398; ĖSBM III: 74). Występuje w gwarach białoruskich północno-zachodniej Białorusi i Litwy (SPZB I: 438) oraz gwarach rosyjskich (południowych i na zachodzie kraju) (SRNG VI: 157). Leksem funkcjonuje w polszczyźnie na Brasławszczyźnie (Smułkowa 2009: 476). КЛЯМКА 'klamka, klamra, zamek'. „Мамкин сундук, приделан клямка и на замочек, все деньги тама" (Korolëva 2013: 131), prawdopodobnie za polskim pośrednictwem (pol. klamka < stpol. klama < śrwysniem. klam; ĖSRÂ II: 259; ÈSBM V: 77). Leksem funkcjonuje w białoruskim języku literackim, występował w języku starobiałoruskim (stbłrs. клямка < pol. klamka < niem. Klinke; Bulyka 1972: 157), gwarach białoruskich, w tym w północno-zachodniej Białorusi (SPZB II: 487), w gwarach rosyjskich (głównie na zachodzie: Briańszczyzna, Smoleńszczyzna, Pskowszczyzna, Litwa, Łotwa) (SRNG XIII: 329, 330). Wyraz występuje także w polszczyźnie brasławskiej (Smułkowa 2009: 280). КЛЯМОЧКА 'klameczka, mała klamra, zamek'. „Клямочка и на замочек и закрыто" (Korolëva 2013: 131), prawdopodobnie za polskim pośrednictwem (pol. klamka, jw.).

СМАЧНЫЙ 6 'smaczny'. „Эта кожурка делается мягкой, когда проспиртуется жирком, делается смачной” (Korolëva 2013: 295), z języka polskiego (pol. smaczny; ĖSRÂ III: 684). Występuje $\mathrm{w}$ gwarach białoruskich północno-zachodniej Białorusi, Litwy i Łotwy (SPZB IV: 502, 503; materiały własne autora) oraz polszczyźnie północnokresowej, w tym na Brasławszczyźnie (SMPPK: 1042; Smułkowa 2009: 312).

СТОДОЛА 'tutaj w znaczeniu: wielki dom'. „Новгородского-то дому некуды деть - там такая стодола! Вот, и у меня сейчас дом как стодола" (Korolëva 2013: 319), za polskim pośrednictwem (pol. stodoła < stwysniem. stadal; ÈSRÂ III: 765), występuje w gwarach białoruskich północno-zachodniej Białorusi i Litwy (SPZB IV: 563) oraz gwarach rosyjskich w Rosji (Pskowszczyzna, gwary wielkołukskie) i na Łotwie (SRNG XLI: 175). Słowo funkcjonuje w polszczyźnie północnokresowej, w tym na Brasławszczyźnie (Smułkowa 2009: 137; Rieger 2014: 110; SMPPK: 1079).

6 Leksemу смачный oraz інстаниьья, кавалерия, капитан, католик zostały zapożyсzone za polskim pośrednictwem już do języka starobiałoruskiego i obecnie funkcjonują zarówno w białoruskim języku literackim, jak też w wielu gwarach. 
ХОЛЕРА 'wykrz., negatywnie wobec człowieka, cholera'. „Иди, холера, сарахван разорвёшь! // Утю, холера, я так и ни знала” (Korolëva 2013: 336), za polskim

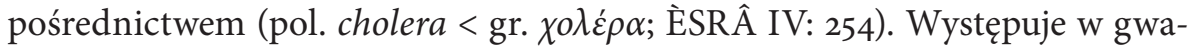
rach białoruskich północno-zachodniej Białorusi, Litwy i Łotwy (SPZB V: 283, 284; materiały własne autora) oraz w polszczyźnie północnokresowej (SMPPK: 163).

$\checkmark$ ХОЛЕРА ЗНАЕТ 'cholera wie'. „Холера знает, куда эти силы уходят - как в песок!” (Korolëva 2013: 336), za polskim pośrednictwem (pol. cholera < < gr. $\chi 0 \lambda \varepsilon ́ \rho \alpha$; ĖSRÂ IV: 254).

ЯРМАРКА 1. 'jarmark’ „В Кокшинах ярмарка, хочется поглядеть, ни за что, я ни с кем не пойду” (Korolëva 2013: 353); 2. 'jarmark świąteczny’ „Тут на гулянье и по ярмаркам ходили везде с Толькой с этым” (ibid.), za polskim pośrednictwem (pol. jarmark < śrwysniem. jârmarket; ÈSRÂA IV: 561; Bulyka 1972: 374), nienotowane w SPZB, występuje w gwarach białoruskich na Łotwie (materiały własne autora) ${ }^{7}$. Leksem znany także w polszczyźnie brasławskiej (Smułkowa 2009: 388).

\section{Wybrane polonizmy w Regionalnym słowniku pskowskim z danymi historycznymi}

Z zapożyczeń z języka polskiego (lub przejętych za polskim pośrednictwem) można wymienić szereg leksemów, które funkcjonowały po II wojnie światowej na obszarze historycznej Pskowszczyzny. Poniżej prezentuję tylko wybrane z dostępnych na ten moment 27 tomów słownika:

БАНКЕТ 'bankiet'. „Там банкет устроили, собралась гульянка” rej. gdowski (POS I: 107), najprawdopodobniej za polskim pośrednictwem (stbłrs. банкеm< $<$ pol. bankiet < fr. banquet lub niem. Bankett < wł. banchetto; Bulyka 1972: 36, 37; ĖSBM I: 303; ĖSRÂ I: 121), funkcjonuje w białoruskim języku literackim, gwarach białoruskich na Łotwie (materiały własne autora), gwarach rosyjskich, w tym na Smoleńszczyźnie (SRNG II: 94).

БАТЬ目ИХА ‘bocianica'. „3 батьянихай жывё, а литая в раскитку” rej. Opoczki, przy granicy z dawną Rzecząpospolitą (POS I: 131), z języka polskiego (pol. bocian; ESRÂ I: 201; ESBM I: 336, 337), występuje w gwarach białoruskich północno-zachodniego pogranicza, w tym na Litwie i Łotwie (SPZB I: 276; materiały własne autora), w SRNG przykłady notowane tylko dla obwodu pskowskiego (SRNG III: 139). W różnych wariantach fonetycznych funkcjo-

7 Niemożliwe jest sprawdzenie hasła w ÈSBM i SRNG, obydwa słowniki nie zostały jeszcze ukończone. 
nuje także w gwarach łatgalskich (LVDA, karta 36). Słowo występuje w polszczyźnie północnokresowej, w tym na Łotwie (SMPPK: 112).

БЫДЛА 'bydło, tutaj także: bodliwa krowa'. „Во, как быдла, схмылилась, збычилась, смотрит с-пада лба" rej. ostrowski, z języka polskiego (pol. bydło; Bulyka 1972: 54; ĖSBM I: 432; ĖSRÂ I: 258), występuje w gwarach białoruskich północno-zachodniego pogranicza, w tym na Litwie (SPZB I: 250), nienotowane w SRNG. Słowo funkcjonuje w polszczyźnie północnokresowej, w tym na Łotwie (SMPPK: 146) oraz na Brasławszczyźnie w postaci bydło i bydła (Smułkowa 2009: 49, 139, 154, 388; Rieger 2014: 72).

ИНСТАНЦИЯ 'instancja'. „Пайдёш па истанциям, начиная с сильсавета” rej. toropiecki (POS XIII: 292), za polskim pośrednictwem (pol. instancja < łac. instantia; ĖSRÂ II: 135; Bulyka 1972: 129), słowniki SRNG i SPZB nie notują, funkcjonowało w języku starobiałoruskim.

ИНТЕРEC 'interes, zainteresowanie, wygoda'. „У кажнава свой интерес. Я лучше свой интерес поимею, чем дым кверху пушшу" (POS XIII: 294), za polskim pośrednictwem (pol. interes lub < niem. Interesse < śrłac. interesse; ĖSR Â II: 136; Bulyka 1972: 130), leksem notowany w gwarach rosyjskich (SRNG XII: 206), gwarach białoruskich północno-zachodniej Białorusi i Litwy (SPZB II: 346) oraz gwarach białoruskich na Łotwie (materiały własne autora).

КАВАЛЕРИЯ 'kawaleria, wojsko konne'. „Миня книга была ета учебная, я в кавалерии патом служыл" rej. gdowski (POS XIII: 187), za polskim pośrednictwem (pol. kawaleria < niem. Kavalier albo franc. cavalier < wł. cavalleria; ĖSRÂ II: 152), leksem funkcjonuje w niektórych gwarach rosyjskich (SRNG XII: 289), SPZB nie notuje słowa.

КАПИТАНН 'kapitan, stopień wojskowy'. „Конь заржал, капитан закричал: чтобы этому коню овса в желобу" źrodła pisane (POS XIII: 470), najprawdopodobniej za polskim pośrednictwem (pol. kapitan < wł. capitano; ÈSRÂA II: 185), słowo występowało w języku starobiałoruskim, do którego trafiło za polskim pośrednictwem (stbłrs. капитанъ < pol. kapitan < wł. capitano < śrłac. Capitulum; Bulyka 1972: 138). Leksem w tym znaczeniu nienotowany w SRNG oraz SPZB. Słowo funkcjonuje w polszczyźnie brasławskiej (Smułkowa 2009: 393). КАТОЛИК 'katolik'. „От, Дуняшкъ и яё фся сямья, ани католики” rej. dnowski; „А он-та [дед Василий] самый сивый чорт и есь, чистый каталик, ево в лужыну хатели тапить, дочык ня пушшал работать” rej. Opoczki, przy granicy z dawną Rzecząpospolitą (POS XIV: 49), najprawdopodobniej za pol-

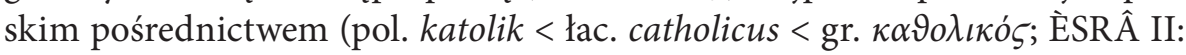
210; ĖSBM IV: 305). Leksem funkcjonował w języku starobiałoruskim (stbłrs.

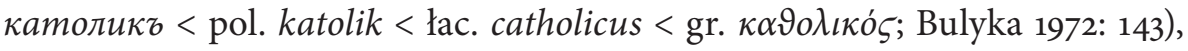
nienotowany w SRNG i SPZB, występuje w polszczyźnie brasławskiej w postaci katolik, kotolik i kotalik (Rieger 2014: 137). 


\section{Podsumowanie}

W odniesieniu do historycznej Pskowszczyzny należy mówić przede wszystkim o kontaktach gospodarczych i urzędowych z Polakami, dlatego też polska leksyka $\mathrm{w}$ tamtejszych gwarach rosyjskich odnosi się głównie do sfery administracji i handlu (np. instancija, interes, manieta 'moneta'). Możemy odnaleźć także słownictwo z zakresu wojskowości (np. kawaleria) oraz związane z posiadaczami ziemskimi i kulturą wysoką. W znamienitej większości są to słowa zapożyczone do języka polskiego z zachodniej Europy (głównie z języków niemieckiego, francuskiego, włoskiego oraz łaciny), od dawna przyswojone i funkcjonujące w polszczyźnie. W regionach graniczących z dawną Rzecząpospolitą funkcjonują także wyrazy polskiego pochodzenia odnoszące się do codziennego życia, gospodarki rolnej czy przyrody (np. bacian, bydła). Na obszarze dawnej guberni pskowskiej nie było osadnictwa polskiego, a co za tym idzie językiem dawcą była tu nie polszczyzna północnokresowa, lecz język ogólnopolski.

Odrębnie należałoby potraktować rejon pytałowski, historycznie stanowiący część Pskowszczyzny (dawnej guberni pskowskiej), ale przez 19 lat (realnie od 1921 do 1940 r., oficjalnie od 1921 do 1945 r.) wchodzący w skład niepodległej Łotwy. Na mowę miejscowej ludności oddziaływały: język łotewski, gwary łatgalskie, gwary białoruskie oraz polszczyzna północnokresowa, która pojawiła się tam na krótki okres wraz z nielicznym polskim osadnictwem (z obszaru Łatgalii) i pracownikami sezonowymi (z Łatgalii i północno-wschodniej II Rzeczypospolitej).

$\mathrm{W}$ dwuczęściowej publikacji został przedstawiony zakres funkcjonowania polszczyzny północnokresowej na pograniczu białorusko-łotewsko-rosyjskim w różnych okresach historycznych oraz jej wpływ na leksykę lokalnych gwar. Leksyka wspólna dla całego badanego obszaru obejmuje przede wszystkim terminologię pochodzącą z języków zachodnich (głównie z niemieckiego, francuskiego, włoskiego, łaciny), która trafiła tu za polskim pośrednictwem. Słownictwo polskie (szerzej - zachodniosłowiańskie) występuje w gwarach rosyjskich i mieszanych białorusko-rosyjskich (historycznie białoruskich) przede wszystkim na obszarze rejonu siebieskiego, newelskiego, pustoszańskiego (wchodzącego do 1772 r. w skład Rzeczypospolitej), rzadziej w rejonie pytałowskim, czyli tam, gdzie było osadnictwo polskie i bezpośredni kontakt Polaków z miejscową ludnością.

Każdy $\mathrm{z}$ trzech omówionych regionów wymaga jeszcze niewątpliwie pogłębionych badań lingwistycznych (m.in. analizy całego słownictwa zawartego w Regionalnym słowniku pskowskim...) wspartych materiałami archiwalnymi oraz analizy dostępnej korespondencji listownej. Umożliwiłoby to w przyszłości pełniejszy opis zakresu użycia języka polskiego na badanym obszarze, przeanalizowanie jego struktury (fonetyki, morfologii, składni i leksyki) oraz porównanie z polszczyzną łotewską i witebską. 


\section{Skróty}

fr. - francuski; gr. - grecki; łac. - łaciński; niem. - niemiecki; pie. - praindoeuropejski; pol. polski; stbłrs. - starobiałoruski; stpol. - staropolski; stwysniem. - staro-wysoko-niemiecki; śrłac. - średniołaciński; śrwysniem. - średnio-wysoko-niemiecki; wł. - włoski

\section{Literatura}

Bulyka A.M., 1972, Daǔnî̀ zapazyčannì belaruskaj movy, Mìnsk.

Dannye vserossijskoj: Dannye vserossijskoj perepisi naseleniâ 2002 goda. Tablica o2c, 34r-Pskov, Moskva 2004.

ÈSBM: V.U. Martynaǔ (red.), Ètymalagǐ̌ny sloǔnik belaruskaj movy, t. 1-, Mìnsk 1978-.

ÈSRÂ: M. Fasmer, Ėtimologičeskij slovar' russkogo âzyka, t. 1-4, Moskva 1986-1987.

Grek-Pabisowa I., 1986, Polonizmy w gwarach pskowskich, [w:] J. Majowa (red.), Jezzyk i jego odmiany w aspekcie porównawczym, „Prace Slawistyczne”, nr 53, Wrocław, s. 183-194.

Jaunlatgales: Jaunlatgales apriņ,ka dzīve un darbs skaițlos, „Brīvā Zeme” 1937, nr 5, [online:] http://www.periodika.lv/periodika2-viewer/view/index-dev.html?lang=fr\&fbclid= IwAR1DKkKvk-hh5 ${ }_{37}$ OBPVT1DkzfGi7uxBLqTXnsYLcxf9TluagXtm5kLY1QQ\#panel: pa|issue:/p_oo1_brze1937n5|article:DIVL776|query:Jaunlatgales\%20Polijas\%20Jaunlat gales|issueType:P (dostęp: 9 XI 2018).

KARAś H., 2017, Język polski pogranicza litewsko-łotewsko-białoruskiego w świetle frekwencji cech jezzykowych, Warszawa.

Korolëva E.E., 2013, Dialektnyj slovar' odnoj sem'i - 2 (Pytalovskij rajon Pskovskoj oblasti), Daugavpils.

KunicKa K., 2012, Jaka jesteś, gwaro dyneburska?, „Rozprawy Komisji Językowej Łódzkiego Towarzystwa Naukowego" LVIII, s. 180-188.

KuṇiCKA K., 2016, Latgales poḷu valoda kā poḷu valodas periferiālais dialekts. Paaudžu atškirību aspekts, rozprawa doktorska, Daugavpils.

LVDA: Latviešu valodas dialektu atlants. Leksika. Kartes, Rīga 1995.

Ostrówka M., 1999, O języku polskim w okolicach Indrycy, „Acta Baltico-Slavica” 24, S. 295-305.

Ostrówka M., 2000, O języku polskim w okolicy Krasławia, „Acta Baltico-Slavica” 25, S. 115-121.

Ostrówka M., 2002, Współczesna polszczyzna mówiona na Łotwie, rozprawa doktorska, Warszawa.

Ostrówka M., Golachowska E., 2018, Sovremennyj pol'skij âzyk v Latvii, „Linguistica Lettica”, 26, Rīga, s. 154-173.

PARŠUtA U.M., 1984, O dialektnoj leksike pol'skih govorov na territorii Latvijskoj SSSR, [w:] J. Rieger, W. Werenicz (red.), Studia nad polszczyzna kresowa, t. III, Wrocław, s. 133-145. POS: Pskovskij oblastnoj slovar's istoričeskimi dannymi, Leningrad / St. Peterburg 1967-.

Pskovskie Govory: N.V. Bol'šakova, L.Â. Kostûčuk (red.), Pskovskie govory i ih issledovateli (k 10o-letiû so dnâ roždeniâ S.M. Gluskinoji 5o-letiû vyhoda 1 vypuska "Pskovskogo oblastnogo slovarâ s istoričeskimi dannymi»), Pskov 2017.

RIEGER J., 2014, Słownictwo polszczyzny gwarowej na Brasławszczyźnie, oparte głównie na nagraniach i zapisach A. Stelmaczonek-Bartnik i in., Warszawa. 
SMPPK: I. Grek-Pabisowa, M. Ostrówka, M. Jankowiak, Słownik mówionej polszczyzny północnokresowej, red. I. Grek-Pabisowa, Warszawa 2017 [preprint].

SmuŁkowa E. (red.), 2009, Brasławszczyzna. Pamięć i współczesność, t. II: Słownictwo dwujęzycznych mieszkańców rejonu (słownik brasławski), Warszawa.

SPIS POWsZeChnY: Spis powszechny 1935, [on-line:] http://pop-stat.mashke.org/latvia-eth nic-comm1935.htm (dostęp: 20 X 2018).

SPZB: U..F. Mackevič (red.), Sloǔnik belaruskih narodnyh gavorak paǔnočna-zahodnâj Belarusi i âe pagraničča, t. 1-5, Mìnsk 1979-1986.

SRNG: Slovar' russkih narodnyh govorov, Moskva 1965-.

STANKEvìč Â., 1962, Pskoǔski dyâlekt, „Zapìsy”, nr 1, s. 178-202.

\section{Relics of the Polish Language of the North-Eastern Borderland in the Former Boundaries of Polish-Lithuanian Commonwealth (Southern Lands of Pskov Province). Part II Summary}

The present paper consists of two parts, and presents the spoken Polish of the North-Eastern Borderland, as well as borrowings from Polish which function in the dialects of the Pskov province. Three regions with different histories have been included. The southern lands of the Pskov province (the area which belonged to the Polish-Lithuanian Commonwealth until 1772) were described in the first part of the article. The sociolinguistic situation and loanwords borrowed from Polish (or via Polish) were analysed basing on two sources: the author's materials collected during dialectological field research, and material from The Pskov Regional Dictionary with Historical Data. The Pytalovo region (which belonged to Latvia in the interwar period) and the historical Pskov region (where there were no Polish settlements) were described in the second part of the paper. Two sources were used: The Pskov Regional Dictionary with Historical Data, and The Dialectological Dictionary of One Family (Pytalovo Region of the Pskov Province). 